\title{
Pemaknaan Fanatisme Bagi Pengguna Vespa di Kota Tangerang
}

\author{
Adhimas Ario Bimo, Gregorius Genep Sukendro \\ Adhimas.915150149@stu.untar.ac.id
}

Fakultas Ilmu Komunikasi Universitas Tarumanagara

\begin{abstract}
In this study, the author used descriptive research methods based from qualitative data, The reference on this research is purely author's interest about the Fanaticism of Vespa users in Tangerang city which can be said that very loyal to the Vespa. This research used phenomenology method to overview the occured phenomenon. According to the purpose of this research, the author would like to see the view of the exist vespa users in Tangerang city about the Fanaticism itself, By using Advert theory and Fanaticism theory, Thus the author choosen his research object such as the community member Moca Vespa, The extreme vespa users and the marketing of Piaggio Tangerang Branch. The result of analyzing and interviewing of the author to the informant revealed that the great Fanaticism that caused the Vespa users keep loyal to use Vespa as their motorcycle however in the progression of technology and transportation like nowadays. Besides they treated Vespa as a best friend, lover even wife. Piaggio has been advert for long time ago before its temporary hiatus. Therefore, Piaggio has already famous and also the fanaticism users. The community factor is also influences the promotion for the exist producer and dealer of Vespa in Tangerang. As we know that we hardly ever see the advert of Vespa at these days. But on the other side we still find many people who are really interested on the product.
\end{abstract}

Keywords: Vespa, Fanaticism, Qualitative

\begin{abstract}
Abstrak
Dalam penelitian ini, penulis menggunakan metode deskriptif dengan data kualitatif. Penulis tertarik dengan pemaknaan fanatisme para pengguna Vespa di Kota Tangerang. Penelitian ini menggunakan metode fenomenologi untuk melihat fenomena yang terjadi. Sesuai dengan tujuan penelitian ini maka penulis ingin melihat pandangan pengguna Vespa yang ada di Kota Tangerang mengenai fanatisme itu sendiri. Dengan menggunakan Teori Iklan dan Teori Fanatisme maka penulis memilih objek penelitian yaitu member komunitas Moca Vespa, pengguna Vespa extreme dan Marketing Piaggio Cabang Tangerang. Hasil analisis dari wawancara yang telah penulis lakukan dengan informan yaitu bahwa kefanatikan membuat member tetap setia menggunakan Vespa di era kemajuan teknologi dan transportasi. Selain itu, Vespa dianggap sebagai sahabat, kekasih bahkan istri. Piaggio sudah beriklan sejak dulu sebelum sempat vakum. Oleh karena itu, Piaggio sudah mendapat nama besar dan pengguna yang fanatik. Faktor komunitas juga sangat mempengaruhi promosi dari produsen dan dealer Vespa yang ada di Tangerang. Seperti yang kita ketahui bahwa di era saat ini sudah jarang dan bahkan tidak ada iklan tentang motor Vespa, namun masih banyak peminat produk tersebut.
\end{abstract}

Kata Kunci: Vespa, Fanatisme, Iklan

\section{Pendahuluan}

Persaingan Industri di bidang kendaraan bermotor dalam beberapa tahun terakhir memang sangat ketat, mulai dari sepeda motor pabrikan jepang yang awalnya menjadi primadona di Indonesia, hingga pabrikan asal Malaysia yang mulai masuk ke pasar Indonesia. Namun yang menarik di Indonesia ini ada pabrikan sepeda motor asal Italy 
yang bernama Vespa. Sempat menjadi penguasa pasar di era-nya, beberapa dekade terakhir produk tersebut seolah sudah tidak mempunyai daya tarik bagi masyarakat, hanya beberapa orang saja yang memang mempunyai hobi mengoleksi Vespa dan sudah jatuh hati terhadap produk tersebut.

Sejak zaman dahulu hingga saat ini, transportasi merupakan alat yang dibutuhkan oleh manusia, transportasi berguna untuk mempermudah kegiatan manusia sehari-hari maupun untuk berpindah dari satu tempat ke tempat lainnya. Semakin majunya perkembangan zaman, semakin berkembangnya jenis transportasi seperti transportasi udara, laut dan darat. Namun masyarakat umum lebih banyak menggunakan transportasi darat dalam kegiatan sehari-hari seperti menggunakan mobil dan sepeda motor. Berkendara menggunakan sepeda motor lebih mendominasi jika dibandingkan berkendara menggunakan mobil, hal ini dikarenakan padatnya lalu lintas disertai dengan tingginya mobilitas masyarakat sehingga masyarakat lebih memilih menggunakan sepeda motor menjadi solusi yang baik untuk digunakan, dari segi ekonomi yang harganya lebih terjangkau dibandingkan dengan harga mobil juga menjadikan sepeda motor sebagai pilihan masyarakat. Vespa merupakan merek sepeda motor jenis scooter dari Italia, perusahaan induk dari Vespa adalah Piaggio yang pada awal kedatangannya Vespa mempunyai saingan berat yaitu scooter Lambretta, sekarang otomatis Vespa sebagai motor scooter konvensional yang tidak mempunyai saingan lagi.

Seperti kita ketahui bahwa Vespa sendiri sangat jarang beriklan di Televisi ataupun di social media lainnya, itu pula yang menyebabkan masyarakat kurang mengetahui tentang Vespa itu sendiri terlebih pada tahun 2004 Vespa mengeluarkan produk terakhir yang diberi nama Vespa New PX dan setelah saat itu Vespa berhenti berproduksi karena peraturan pemerintah Indonesia yang melarang kendaraan bermotor 2 Tak beroperasi.Setelah sekian lama berhenti berproduksi, pada tahun 2010 Piaggio mengeluarkan produk baru tetapi dengan model berbeda yaitu, skuter matic 4 Tak untuk bisa bersaing dengan pabrikan lain yang sudah menguasai pasar Indonesia di bidang industri kendaraan b ermotor. Vespa sendiri sejatinya sudah memiliki nama yang cukup besar walaupun sempat hilang dikarenakan berkembangnya teknologi. Sekarang tinggal bagaimana Piaggio memulai kembali persaingan dan mulai memikat hati konsumen supaya bisa bersaing dengan pabrikan-pabrikan lama.

Di kota Tangerang sendiri terdapat banyak sekali pengguna dan komunitas Vespa yang tersebar di berbagai daerah, beberapa pengguna dan komunitas tersebut hampir mayoritas memiliki fanatisme yang kuat terhadap Vespa serta memiliki rasa solidaritas yang kuat bagi sesama pengguna vespa. Untuk di kota Tangerang sendiri rata-rata komunitas dan pengguna Vespa, mayoritas hanya menggunakan 2 jenis Vespa yaitu Vespa Classic dan Vespa Modern. Seperti yang saya ketahui mengenai Vespa Modern dan Vespa Classic itu mempunyai komunitas yang berbeda-beda. Jika Vespa Modern itu sendiri, mereka cenderung membentuk dan mendandani Vespa mereka dengan bentuk yang mereka inginkan seperti di buat racing look, classic dan masih banyak lagi. Jika Vespa Classic mereka cenderung mempertahankan produk sesuai dengan keluaran pabrik, bisa dibilang mereka menjaga ke orisinilan barang. Pada penelitian ini peneliti menggunakan teori Fenomenologi (fenomena) yaitu salah satu metode pemcarian data dalam metode penelitian kualitatif. Fenomenologi merupakan sebuah aliran filsafat yang menilai manusia sebagi sebuah fenomena. Fenomenologi mempelajari tentang arti kehidupan beberapa individu dengan melihat konsep pengalaman hidup mereka atau fenomenanya. Fokus dari fenomenologi adalah melihat apakah objek penelitiannya memiliki kesamaan secara universal dalam 
menanggapi sebuah fenomena. Fenomenologi adalah ilmu yang menjelaskan dan mengklarifikasi sebuah fenomena, atau studi tetang fenomena. Dengan kata lain, fenomenologi mempelajari tentang fenomena yang nampak di depan mata dan bagaimana penampakannya.

Fanatisme yang merupakan bentuk rasa cinta yang berlebihan hingga akan berdampak luar biasa terhadap sikap hidup seseorang. Segala sesuatu yang diyakini akan memberikan sebuah kecintaan dan semangat hidup yang lebih pada orang tersebut. Dalam kehidupan sehari-hari fanatisme juga dapat diartikan sebagai kesenangan yang berlebihan (tergila-gila). Fenomena ini menjadi tambahan kekuatan bagi Piaggio Indonesia yang memiliki komunitas dan pengguna Vespa yang sangat banyak hampir di setiap daerah dan para pemilik Produk Piagio biasanya fanatik dan loyal. Fenomena ini juga merupakan sebuah realitas yang terjadi di tengah masyarakat karena realitas tersebut merupakan sesuatu hal yang tadinya tidak ada.

Alasan peneliti mengenai fenomena fanatisme Pengguna Vespa di Tangerang adalah untuk menghetahui pandangan dari 2 jenis pengguna Vespa yang ada di kota Tangerang, mulai dari Vespa Classic dan Vespa Modern mengenani fanatisme yang cukup mencolok dan sudah mulai dikenal sebagai Pengguna dan Komunitas yang loyal terhadap produk Piagio Indonesia.

\section{Metode Penelitian}

Dalam penelitian ini penulis menggunakan metodi penelitian kualitatif guna menganalisis tentang femonena fanatisme yang sangat melekat di kalangan para pengguna vespa dan komunitas vespa yang ada di Kota Tangerang. Seperti yang di katakan oleh Nazir (2011) metode penelitian adalah suatu metode dalam meneliti status kelompok manusia, suatu objek, suatu set kondisi, sistem pemikiran ataupun suatu kelas peristiwa pada masa sekarang. Dalam penelitian ini, penulis menggunakan metode penelitian kualitatif. Menurut Burhan Bungin, penelitian kualitatif adalah penelitian yang memiliki tingkat kritisme yang lebih dalam dari semua proses penelitian maka kekuatan kritisme peneliti menjadi senajata utama menjalankan proses penelitian (Bungin, 2011)

Berdasarkan pendekatan dan jenis data yang digunakan, penelitian ini termasuk ke dalam penelitian kualitatif sehingga akan menghasilkan data deskriptif berupa katakata. Data yang dianalisis di dalamnya berbentuk deskriptif dan tidak berupa angkaangka seperti halnya pada penelitian kuantitatif. Menurut Arikunto (1998) penelitian kualitatif dimaksudkan untuk mengumpulkan informasi mengenai status suatu gejala yang ada, yaitu keadaan gejala menurut apa adanya pada saat penelitian itu dilakukan. Oleh karena itu, penelitian kualitatif mampu mengungkap fenomenafenomena pada suatu subjek yang ingin diteliti secara mendalam.

Pada penelitian ini peneliti melakukan pengumpulan data melalui studi pustaka, observasi, wawancara, dan penelusuran online. Subjek dalam penelitian ini adalah Bapak Irvan dan bapak deni selaku pihak dari Vespa Sinergi Tangerang yang Berlokasi di jalan Merdeka no. 233 (arah ke Cimone), tepat di depan Hotel Merdeka (baru) atau di sebelah Hotel Merdeka (lama) dan juga kepada Jeven Russel Gibran selaku member dari Mocaves Tangerang. 


\section{Hasil Temuan dan Diskusi}

Hasil temuan dan diskusi tentang Fanatisme ini akan peneliti paparkan sebagai berikut: berdasarkan hasil wawancara dengan Jeven Russel selaku member dari komunitas Mocaves Tangerang bahwa fanatisme sudah melekat dari dulu sehingga itu pula yang menyebabkan loylitas bagi pengguna vespa kepada produk dan merk vespa itu sendiri. Selain itu juga Fanatisme ini menyebabkan penggunanya sangat mengidamkan akan vespa sehingga tidak peduli dengan merk apapun selain vespa. Hal itu di karenakan vespa sendiri sudah menjadi kendaraan yang paling popular dimasa lalu. Vespa memang memiliki banyak arti bagi penggunanya dan mempunyai nilai sendiri, menurut Jeven Russel vespa itu tak lekang oleh waktu seperti cinta, saking cintanya dengan vespa sampai dia tak peduli ada motor yang lebih keren seperti Harley Davidson dan juga mobil mewah seperti BMW karena dia akan menggunakan vespa sampai tua.

Gambar 1. Kegiatan Riding Mocaves

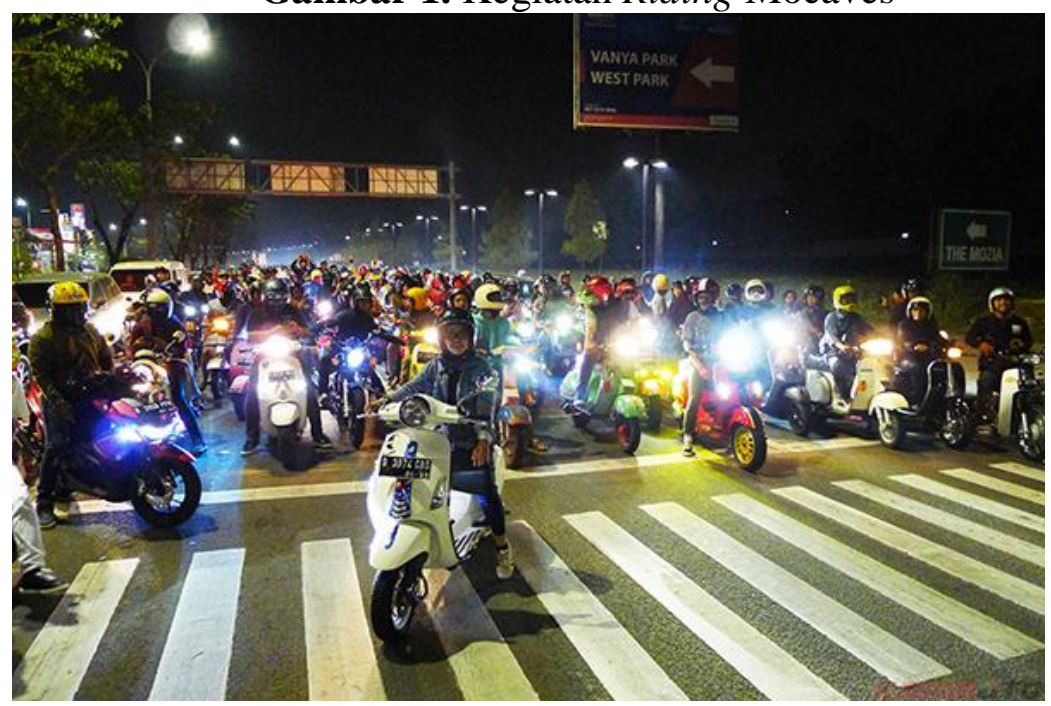

Sumber: Kabaroto.com

Pada Gambar di atas merupakan salah satu komunitas Vespa yang bernama Mocaves (Modern Classic Vespa) yang berada dikawasan Tangerang sedang melakukan kegiatan riding. Mocaves adalah suatu komunitas vespa yang ada di Tangerang dan juga sebagai tempat berkumpulnya para pecinta vespa baik vespa matic ataupun vespa classic. Terlebih Mocaves itu adalah suatu komunitas vespa yang mempersilahkan setiap pengguna vespa baik itu vespa classic atau vespa modern untuk bergabung ke komunitasnya tersebut tidak mengkelopok-kelompokan jenis vespa yang di gunakan. Komunitas sendiri terbentuk dengan adanya kesamaan dalam tujuan dan apa yang disukai atau diminati sebagai contohnya komunitas Vespa Mocaves. Hal itu sependapat dengan teori komunitas yang dikatan oleh Menurut Soerjono (1990). Komunitas dibentuk bukan tanpa tujuan. Bisa tujuan jangka pendek, menengah, atau jangka panjang.

Vespa sendiri sempat berhenti berproduksi dikarenakan pada tahun 2009 di Indonesia dikeluarkan pasal 210 dan 211 Undang-undang No 22 Tahun 2009 tentang motor 2 tak di larang beroperasi, Oleh karena itu vespa kembali hadir dengan varian 4 tak yang lebih ramah lingkungan. Dengan nama besar vespa sebagai salah satu 
produsen otomotif yang sudah malang melintang di Indonesia maka tidak sulit bagi vespa untuk kembali meramaikan pasar otomotif dengan produk barunya.

Gambar 2. Launching Vespa Modern Pertama Kali Di Pekan Raya Jakarta 2010

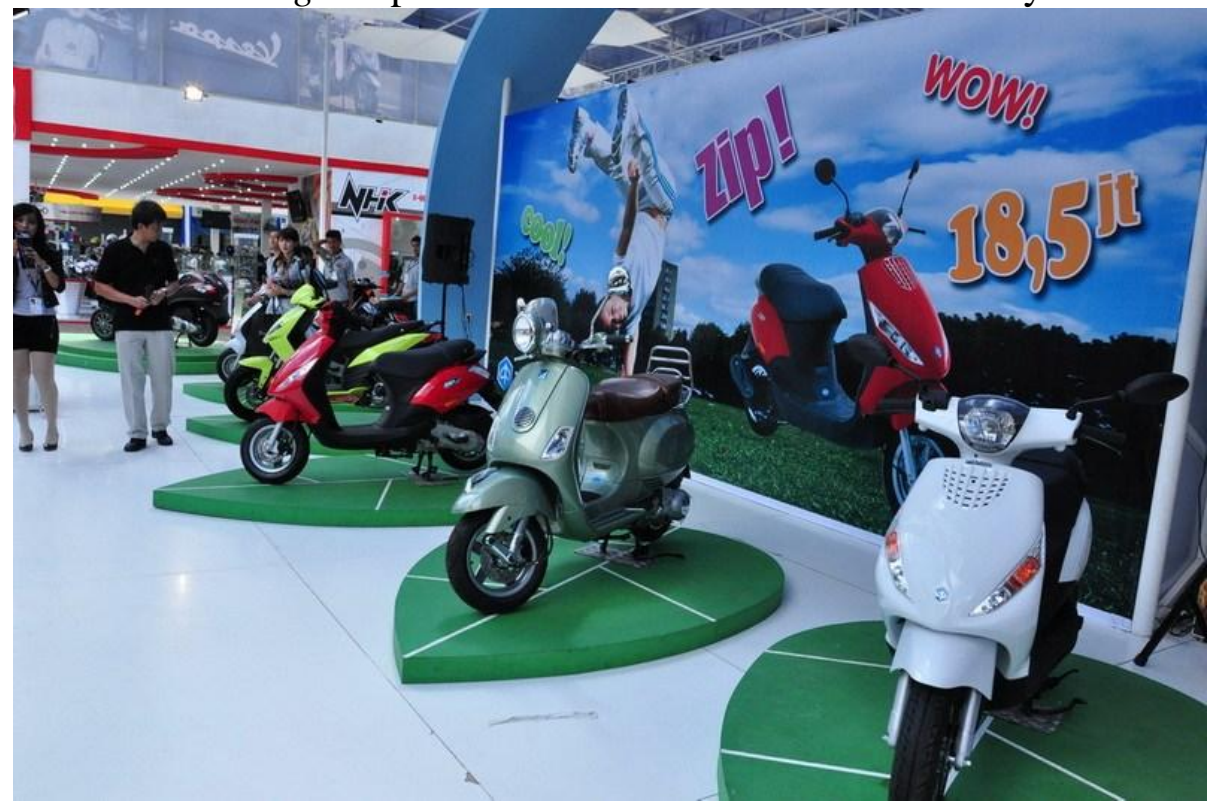

Sumber: Stphenlangitan.com

Komunitas menjadi salah satu komponen promosi bagi dealer vespa yang ingin memasarkan produk baru, seperti yang di ungkapkan oleh Bapak Irvan selaku kepala cabang Vespa Sinergi Tangerang, menurutnya bahwa kenyataan nya memang komunitas sangat berperan penting terhadap promosi produk vespa itu sendiri. Dengan meminjamkan 5 unit produk baru kepada salah satu komunitas yang ada di Tangerang, Dealer secara tidak langsung dapat melakukan promosi produk barunya. Komunitas yang di titipkan unit terbaru pun bebas memakai kendaraannya secara bergantian selama satu bulan, hal ini sangat menarik karena vespa memang mengincar pasar yang sudah familiar dan fanatik dengan produknya sehingga tidak perlu repot-repot beriklan di telivisi dan juga mengeluarkan biaya pemasaran yang banyak untuk memasarkan dan memperkenalkan unit baru yang mereka keluarkan.

Dengan cara promosi seperti itu Vespa Sinergi Tangerang memang mengharapkan adanya promosi dari mulut kemulut antar member di komunitas tersebut atau bahkan komunikasinya antar satu komunitas dengan komunitas lain nya yang ada. Apa yang dikatakan oleh bapak Irvan di atas memang sependapat dengan teori yang telah dikemukakan oleh Kotler and Armstrong (2012) bahwa word of mouth communication adalah komunikasi pribadi tentang sebuah produk antara pembeli sasaran dan tetangga, teman-teman, anggota keluarga dan rekannya dan teori yang dikemukakan oleh Kotler and Keller (2009) menjelaskan word of mouth adalah kegiatan pemasaran melalui perantara orang ke orang baik secara lisan, tulisan, maupun alat komunikasi elektronik yang berhubungan dengan pengalaman pembelian jasa atau pengalaman menggunakan produk atau jasa.

Hal ini yang menurut penulis perlu di perhatikan karena bagaimana suatu produk dapat diketahui dan diminati oleh pasar padahal vespa sama sekali tidak beriklan di televisi, menurut penulis hal yang menjadi salah satu faktor tinggi nya minat beli terhadap suatu vespa yang jarang beriklan adalah faktor fanatik yang dimiliki oleh masyarakat terhadap vespa itu sendiri. Fanatisme memang menjadi salah satu faktor 
mengapa vespa mejadi salah satu penguasa dibidang industri otomotif di Indonesia. teori fanatisme yang di kemukakan oleh Goddard (2001) adalah suatu keyakinan yang membuat seseorang buta sehingga mau melakukan segala hal apapun demi mempertahankan keyakinan yang dianutnya.

Kecintaan sangat besar kepada produk vespa lah yang menyebabkan para penggunanya terlebih pengguna vespa sejak jaman dulu yang sampai sekarang menggunakan vespa, menyebabkan fanatisme yang sangat kuat bagi mereka, sehingga tidak peduli apakan produk terbaru vespa ada iklannya di televisi atau tidak sekalipun mereka tetap mencari tahu dengan sendirinya tentang produk tersebut dan bahkan bisa melakukan keputusan pembelian.

Konsumen vespa di Tangerang sekarang itu rata-rata masih belia seperti anak Sekolah Menengah Atas dan juga Mahasiswa, karena sekarang vespa sudah bertransformasi menjadi produk yang lebih baru dan lebih menarik minat anak muda. Seperti yang di katakan Irvan selaku kepala cabang Vespa Sinergi Tangerang bahwa produk vespa sekarang memang harganya jauh lebih mahal ketimbang produk motor merk lain namun harga tersebut sebanding dengan nilai sejarah dan kontribusi brand brand vespa sebagai salah satu akomodasi terpopuler di Indonesia jaman dulu. Sumbangsih vespa bagi bangsa juga seperti memberikan beberapa unit vespa kepada TNI Kala itu pasukannya dinamakan Kontingen Garuda (Konga). Pada tahun 1956 pasukan Konga I dikirim ke Mesir. Vespa berkode mesin VNB2, VGLA dan VGLB ini buatan Jerman bukan Italia. Konon, karena dibuat di Jerman, Vespa ini punya plat bodi yang lebih bagus dan kuat dari Vespa biasa.Salah satu ciri khas lain di Vespa Kongo adanya lambang Garuda di bodi depan sebelah kiri. Perbedaan lainnya ada di BPKB (Buku Pemilik Kendaraan Bermotor). Di dalam BPKB tertulis ex Brigade Garuda.

\section{Simpulan}

Makna fanatisme bagi pengguna vespa di Kota Tangerang adalah cinta, rasa cinta yang besar terhadap vespa dapat menimbulkan solidaritas yang tinggi bagi sesama pengguna vespa di kota Tangerang. Peran komunitas sangat besar terhadap perkembangan kreatifitas pengguna vespa di kota Tangerang karena di komunitas itu mereka dapat melakukan berbagai macam hal positif. Fanatisme juga yang mendasari terbentuknya komunitas karena ada kesamaan pendapat dan hobi, serta komunitas juga berperan penting bagi dealer Vespa Sinergi Tangerang selaku penjual produk vespa yang ada di kota Tangerang. Peran Word of Mouth sangat berpengaruh terhadap penjualan produk vespa yang ada di kota Tangerang, karena produk vespa sama sekali tidak diiklankan di televisi dan hanya mengandalkan Word of Mouth dari para pengguna dan komunitas yang ada di kota Tangerang.

Dari beberapa poin diatas dapat di ketahui makna fanatisme bagi pengguna vespa di Tangerang dapat mempengaruhi keseharian mereka sebagai pengguna, mulai dari solidaritas yang kuat dan juga dapat membentuk sebuah keluarga baru yang di sebut komunitas. Serta peran komunitas sangat besar bagi promosi dan penjualan produk vespa itu sendiri di kota Tangerang. 
Adhimas Ario Bimo, Gregorius Genep Sukendro: Pemaknaan Fanatisme Bagi Pengguna Vespa di Kota Tangerang

\section{Ucapan Terima Kasih}

Ucapan terima kasih penulis berikan kepada narasumber yang telah meluangkan waktunya dan memberikan informasi kepada peneliti selama proses pengumpulan data dalam penelitian ini. Peneliti juga ingin mengucapkan terima kasih kepada dosen pembimbing serta Fakultas Ilmu Komunikasi Universitas Tarumanagara.

\section{Daftar Pustaka}

Bungin, Burhan. (2006). Metodologi Penelitian Kuantitatif. Jakarta: Kencana.

Chaplin, J.P. (2009). Kamus Lengkap Psikologi (Terjemahan Kartin Kartono). Jakarta: PT Raja Grafindo Persada.

Goddard, H. (2001). Civil Religion. New York: Cambrige University Press.

Haryatmoko. (2003). Mencari Akar Fanatisme Ideologi, Agama atau Pemikiran. Jakarta: Ghalia Indonesia.

Ibrahim, Deri. (2014). Pemaknaan Vespa Ekstreme bagi pengguna vespa ekstreme di kota pekanbaru dalam prespektiffenomenologi. Universitas Riau.

Ismail, Saifullah. (2014). Komunitas Vespa Di Kota Makassar (Studi Tentang Gaya Hidup). Universitas Hassanudin Makasar.

Kuswarno, Engkus. (2009). Metodelogi Penelitian Fenomenologi: Konsepsi, Pedoman dan Contoh Penelitian. Bandung: Widia Padjajaran.

M. Hariwijaya \& Bisri M. Djaelani, (2008). Teknik Menulis Skripsi dan Thesis, Yogyakarta: Hanggar Kreator

Nazir. Mohammad, Ph.D. (2011). Metode Penelitian. Jakarta: Ghalia Indonesia

Schultz, D. \& Schultz, E. S. (2010). Psychology and work today (10 edition). New York: Pearson.

Seregina, A., Koivisto, E., \& Mattila, P. (2011). Fanaticism-Its Developmentand Meanings in Consumers Lives. Journal of Aalto University School of Economics. 1 (1), pp 1-106.

Sernovitz, Andy. (2012). Word of mouth marketing. Kaplan Publishing.

Soekanto, Soejono. (1990). Sosiologi Suatu Pengantar. Jakarta: PT Raja Grafindo Persada.

Soenarno. (2002). Kekuatan Komunitas Sebagai Pilar Pembangunan Nasional. Jakarta.

Streubert, \& Carpenter. (2003). Langkah Analisis Data Penelitian Kualitatif Model Colaizzi.Cokroaminoto.

Sukendro, G. G., \& Bintari, Tanti Anastasya. (2018). Pola Komunikasi Kelompok Lokananta Record dengan Komunitas Lokananta Project Dalam Membentuk Kohesivitas Kelompok.

http://hai.grid.id/read/07594603/vespa-di-indonesia-ini-terbuat-dari-pohon-tapi-bisatouring-ke-aceh-salut-banget?page=all

http://stephenlangitan.com/archives/15043

http://www.menulisproposalpenelitian.com/2013/03/langkah-analisis-datakualitatifmodel.html diunduh Senin, Maret 11, 2013

https://kabaroto.com/post/read/tangerang-nite-ride-6-ajang-riding-sambil-beramaluntuk-palu

https://merahputih.com/post/read/mengenal-komunitas-vespa-mocaves

https://motorplus.gridoto.com/read/04212310/gokil-ini-vespa-paling-bersejarah-diindonesia-harganya-menggila\#! $\% 2 \mathrm{~F}$ 